\title{
レーザー生成プラズマX線を用いた遠隔透視
}

\author{
森 芳孝 ${ }^{1}$, 葉原一 ${ }^{2}$, 石井 勝弘 ${ }^{1}$, 花山 良平 ${ }^{1}$, 川嶋 利幸 ${ }^{3}$, 北川 米喜 ${ }^{1}$ \\ '光産業創成大学院大学 (广431-1202 静岡県浜松市西区員松町1955番1) \\ ${ }^{2}$ (株) IHI（テ235-8501 神奈川県横浜市磯子区新中原町1番地） \\ 3浜松ホトニクス (株) 産業開発研究所 ( ₹ 431-1202 静岡県浜松市西区呉松町1820)
}

\section{Stand-Off Detection of Hidden Objects by Laser Plasma Induced X-Rays}

\author{
Yoshitaka MORI, ${ }^{1}$ Hajime KUWABARA, ${ }^{2}$ Katsuhiro ISHII, ${ }^{1}$ Ryohei HANAYAMA, ${ }^{1}$ \\ Toshiyuki KAWASHIMA, ${ }^{3}$ and Yoneyoshi KITAGAWA ${ }^{1}$ \\ ${ }^{1}$ The Graduate School for the Creation of New Photonics Industries, 1955-1 Kurematsu-cho, Nishi-ku, Hamamatsu, Shizuoka 431-1202 \\ ${ }^{2}$ IHI Corporation, 1 Shin-Nakahara-cho, Isogo-ku, Yokohama, Kanagawa 235-8501 \\ ${ }^{3}$ Hamamatsu Photonics K.K., 1820 Kurematsu-cho, Nishi-ku, Hamamatsu, Shizuoka 431-1202
}

(Received August 22, 2012)

\begin{abstract}
We proposed the stand-off inspection of unknown or hidden objects by a laser-produced X-ray that has a great potential for security applications or disaster relief. To demonstrate its principle, ultra-intense laser-produced sub-ps X-ray pulses detected backscattered signals from objects hidden in a container with the coincident technique. Coincident measurement with primary X-rays enabled differentiation inside an aluminum container among the following object materials: acrylic, copper, and lead blocks. The spectrum of these backscattered signals can distinguish the atomic number of the materials. To realize a collimated X-ray source to scan these objects, we proposed X-ray generation by inverse Compton scattering of laser-plasma accelerated electrons. We also presented the present status of this $\mathrm{X}$-ray generation.
\end{abstract}

Key Words: Laser plasma, TW-laser, X-rays, Back scatter, Inverse Compton scattering

1.はじめに

透過力の高いX線は対象物の透視像を見るのに適して おり, X線を用いた透視撮像技術は, 医療分野, 科学分 析分野, 産業分野などで幅広く利用されている。しか し, これまで実用化されているX線透視装置の大半は透 過型X線強度計測器であり, その適用範囲には制限が あった。これらの装置では測定対象に近接する必要性が あり，遠隔物及び大型構造物を対象とできる透視技術開 発は進んでいないのが現状である。

一方，国内外に扔いて輸送・物流や大型集客施設に打 ける安全保障に対する認識が高まっており，不審物を非 接触で遠隔から透視する技術への要望が高まっている.

この遠隔透視技術は，セキュリティー分野のみならず橋 梁及び橋脚など大型構造物の非破壞検査の分野でも応用 の可能性を持つ技術である, 我々は, レーザー加速電子 線を用いたレーザー逆コンンプトン散乱X線を利用し て, 遠隔から対象物を検知する遠隔透視の研究を進めて 㧍り, 非接触不審物検査や人の接近が困難な場所の非破 壊検查等への適用を想定している ${ }^{1-3)}$ 。本稿では, レー ザー生成プラズマからの短パルスX線を用い, 被検查体 からの後方散乱X線を観測することによって, 原子番号
の異なる材質を区別して検知した遠隔透視の原理実証の 結果, 及びレーザー逆コンプトン散乱過程によるペンシ ルビームX線源開発の状況を報告する。

\section{2.レーザー生成X線の特長と遠隔透視技術との整合性}

X線応用でまず思いつくのはレントゲン写真であろ う。筆者も，2007年の秋頃，レーザープラズマからのX 線発生を確認した際にレントゲン写真撮影を試みた。

Fig. 1に示すのは, レーザープラズマX線源で撮像した 稲穂のレントゲン像である。イメージングプレートの前 に稲穂をセットし，レーザーをアルミ板表面に集光する ことで，制動放射線を発生した. $10 \mathrm{~Hz}$ で1分連続照射し たものである。レーザー生成X線を透過画像として用い る研究は精力的にすすめられており, 点光源であること

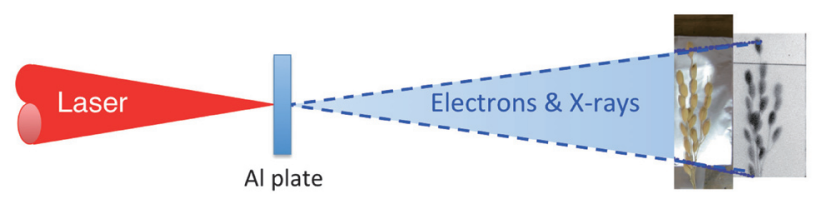

Fig. 1 Radiography of an ear of rice inaho taken by laser plasma induced X-ray. 
を利用した屈折率位相差イメージング4,5), 及び小型装 置であることを利用した狭部診断用X線イメージングシ ステム ${ }^{6}$ が提案されている.

一方, レーザー生成X線の特徴は, 短パルス性と高輝 度にあり，レーザーの繰り返しを1〜1000 Hzとすると， 平均光子数はX線管と同程度であるもののピーク光子数 は放射光線源に匹敵する. Fig. 2 は種々のX線源の特徵 を比較したものであり，レーザー生成X線源について最 近の報告をプロットした，X線で遠隔透視を実現するた めには，この短パルス高輝度性を活用する，X線を用い て対象物を透視する手法として, 透過X線を検出する方 法と後方散乱X線を検出する方法がある．前者はレント ゲン写真として一般的であるが, 線源と検出器の間に対 象物を設置するため, 検出器を対象物に近づける必要が あり遠隔からの適用は難しい. そこで, 後者の後方散乱 X線について考えてみる。近年の光計測技術の進展によ り, X線領域での単一光子計測が可能であり, 大面積X 線検出器を用いれば遠隔物からの微弱後方散乱X線を検 出することは不可能ではない. しかし, 一般の環境では 自然放射線が存在し, 後方散乱X線信号に対するノイズ となって遠隔透視の実現を困難としていた，短パルス高 輝度X線を用い, X線検出器をX線パルス幅の間のみ同 期計測すれば，後方散乱X線信号と自然放射線信号の比 は大幅に改善される。

以上の考察をもとに, Fig. 3に示すようなレーザー生 成X線による遠隔透視システムを考案した，装置はト レーラーに搭載してあり, 対象物から約 $10 \mathrm{~m}$ の距離まで 移動する。そそこで，レーザープラズマ生成パルスX線をレー ザー光線のように遠隔の物体へスキャニング照射し，そ の内部構造をX線の散乱( いわゆる後方散乱)で検出し, 2次元画像として再構築する。X線光量の定量評価によ れば, 対象物体を厚み $30 \mathrm{~cm}$ 水とした場合, 光量 $10^{6}$ photons/pulseのX線を照射したとき，約400 photons/pulse が後方散乱信号として直径 $2 \mathrm{~m}$ の線検出器にかかる.

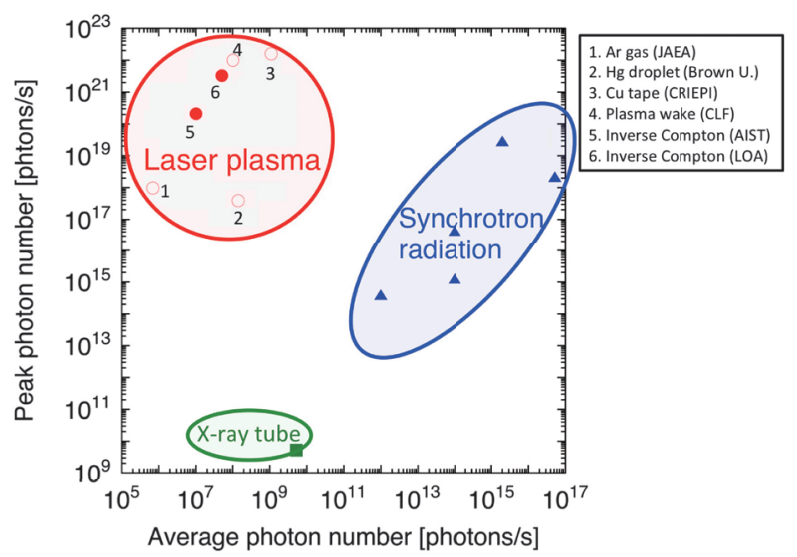

Fig. 2 Characteristics of X-ray sources: average photon number v.s. peak photon number. Open-circles are deduced data from experiments of laser plasma X-ray reported from JAEA, ${ }^{4)}$ Brown U., ${ }^{5)}$ CRIEPI, and CLF. ${ }^{7)}$ Close-circles represents inverse Compton source by laser plasma electron from AIST, and LOA. ${ }^{9}$
これは自然放射線からのバックグラウンドノイズを十分 識別できうる值である。遠隔透視装置はトレーラーに搭 載できる程度まで小型化される必要がある。直径 $2 \mathrm{~m}$ の 検出器を採用すると, 装置の大きさはX線発生装置で決 定され，これはX線発生部が小さい為レーザー本体の大 きさとなる. 出力ジュールクラスの超短パルスレーザー はレーザーコンポーネントの積層化などにより装置の小 型化が十分に期待でき，実際，トラック可搬型のエネル ギーsub-JクラスのTWレーザー装置が仏国Amplitude社よ り市販されている、X線発生部もふくめたモバイル化が 実現すれば，遠隔透視を必要とする不審物検査，大型構 造物非破壊検査, 及び梁害の現場へ赴くことが可能とな る.

\section{3. 後方散乱X線を用いた遠隔透視の原理実証実験}

後方散乱X線を用いた遠隔透視の実現性検討のため, Fig. 4に示すような実験レイアウトを構築した。超短パ

\section{Mobile inspection}

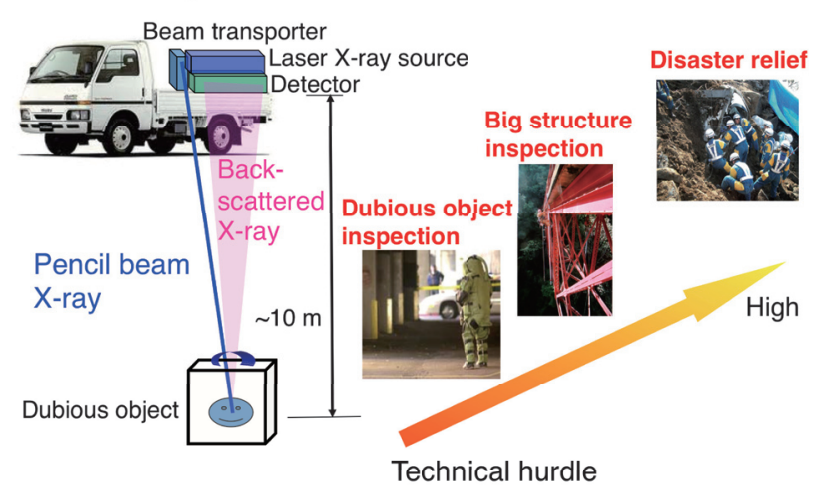

Fig. 3 Stand-off mobile inspection system to reveal a dubious object. A laser-produced pencil beam x-ray scans the object then the backscatter signals from it are decomposed to provide an image.

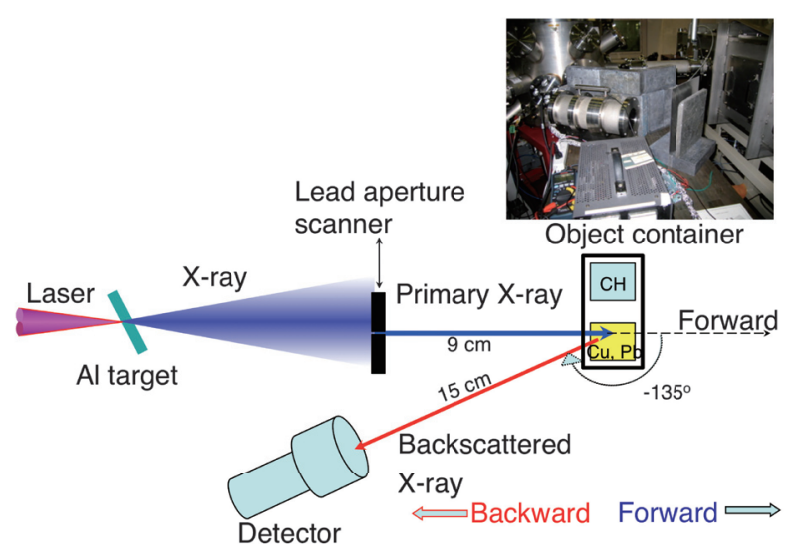

Fig. 4 Experiments setup for backscatter inspection of hidden-object by using laser-produced X-rays. A laser (left) is focused on an aluminum target, generating picosecond pulse X-rays, which travel through a movable lead collimator (center) to scan the objects in an aluminum container (right). Backscattered X-rays reach the scintillation detector (center-bottom). 
ルスX線源として, 超短パルスレーザーを固体平板に照 射する方式を用いた。レーザーは光パラメトリック チャープパルス増幅 (Optical Parametric Chirped-Pulse Amplication: OPCPA) を前段増幅器に有するチタンサ ファイアレーザーBEAT ${ }^{10,11}$ であり，エネルギー $62 \mathrm{~mJ} / \mathrm{pulse}$, パルス幅 $(F W H M) 200 \mathrm{fs,}$ 集光強度 $1.9 \times 10^{17} \mathrm{~W} / \mathrm{cm}^{2}$, 繰

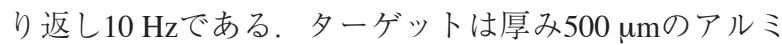
平板である。ターゲット面に対しレーザーはP偏光, レーザー入射角度 30 ○で照射した。 ターゲットを $50 \mu \mathrm{m} / \mathrm{s}$ で連続的に移動させながらレーザー照射を行い, レー ザー照射面の状態を各ショットで常に一定としてX線発 生を行った。X線は、レーザー軸上に設置した厚み $5 \mathrm{~mm}$ のBK7空から取り出した。これを一次X線とする。 レーザーターゲットからほぼ全立体角に放出される一次 X線を，鉛ブロック2個を間隔 $5 \mathrm{~mm}$ 空けて並べた鉛コリ メータで，幅 $5 \mathrm{~mm}$ の短冊X線源とした。鉛コリメータ を移動することで一次X線のスキャンを実現した。

散乱体には，アクリル，鉛及び銅の角ブロックを用い た。後方散乱X線測定では, X線発生点から散乱体まで の距離を $1325 \mathrm{~mm}$ に固定し, 散乱体と後方散乱X線検出 器間距離を $150 \mathrm{~mm}$ で測定した。検出器はプラスチック シンチレータ (Saint-Gobain Crystals社製，材質BC-404), 光電子増倍管 (浜松ホトニクス, 型番H8443)を組み合わ せたもので，受光サイズ $\phi 90 \mathrm{~mm}$ である。信号のカウン トはレーザー照射後の前後-15〜185 nsの200 nsの間にX 線検出信号が入った条件でのみカウント及び波形取り込 みを行った。

まず，後方散乱の特性評価のため，散乱体の材質(ア クリルと鉛) 及び厚みに対する散乱X線の強度依存を実 測した結果をFig. 5に示す。鉛コリメータは固定してい る. 図中に示したバックグラウンドは, 散乱体を取り除 いた状態で一次X線を照射した場合の計測值である。こ の結果は, 極めて微弱な後方散乱X線でも, 極短パルス X線を用いたパルス同時計測により, 散乱体物質, 厚さ に依存した後方散乱X線を有意な差をもって計測可能で あることを示している. 図中の曲線は理論モデル計算値 で, 散乱体中でのX線減衰とX線－電子衝突による単発

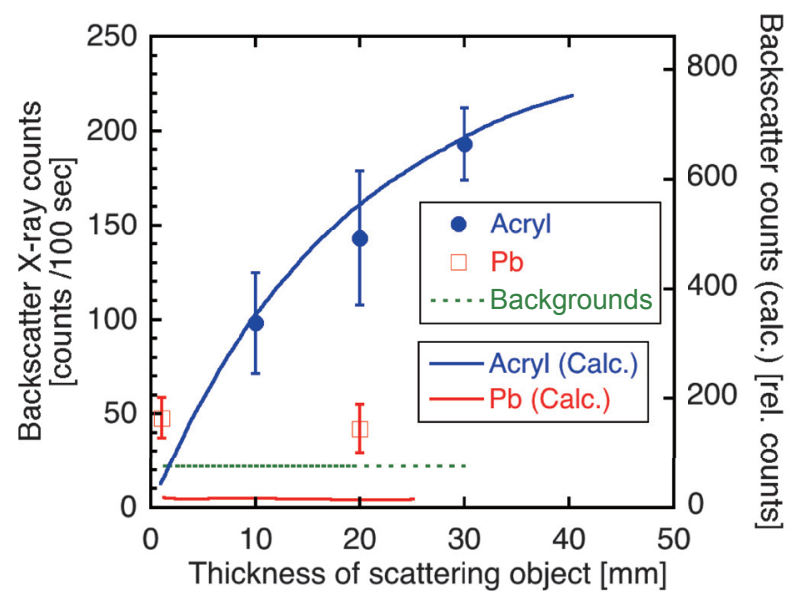

Fig. 5 Backscatter X-ray counts as a function of object thicknesses for Acryl (closed-circles) and $\mathrm{Pb}$ (open-squares).
のコンプトン散乱を考慮しており，一次X線強度をパラ メータとして実験結果とフィッティングした，材質の違 いによる定量性評価には課題が残るが，同一材質におけ る厚さ依存性を良く説明できている.

Fig. 6は, 1次X線スペクトルと散乱光スペクトルを規 格化したものである。一次X線のエネルギースペクトル 測定には, Amptek. Inc.のCdTe半導体検出器：XR100に 開口径 $1 \mathrm{~mm}$ のコリメータを装着し, 1 photon/pulse以下 の計測条件で多パルスの積算計測をおこなった，X線取 り出し空により，エネルギー $20 \mathrm{keV}$ 以下のX線はカット されている。散乱スペクトルは, 散乱体の材質に依存し て，入射スペクトルからの変形をうけ，例えば，鉛が散 乱体のときは1次X線の低エネルギー成分の吸収が生じ ている.この結果は, 後方散乱X線のスペクトル測定に より，遠隔透視と同時に物質判定ができる可能性を示し ている.

以上の後方散乱X線の特性を踏まえ, 鉛コリメータで X線をスキャンし遠隔透視を試みた。対象物として, 厚 み $1 \mathrm{~mm}$ のアルミニウムケースの中に封じた銅(厚み $5 \mathrm{~mm}$ ), 鉛(厚み $1 \mathrm{~mm}$ ), アクリル(厚み $30 \mathrm{~mm}$ )を採用し た. Fig. 7 (a) に対象物の写真を, Fig. 7 (b) 及び(c)に後 方散乱強度分布計測結果を示す。各点のカウント数は, 1000 ショット (100秒) 連続計測の積算である. Fig. 5 と比 ベると，アルミケースが吸収体となって散乱信号のカウ ント数は低減しているが, アルミニウムコンテナー内に 隠れていて肉眼では確認できない物体の存在を，後方散 乱計測により推測できることを実証している，後方散乱 では，散乱体を構成する元素の原子番号が小さくて厚い 物体の方が信号をよく散乱するため, 金属等の検知を得 意とする透過型計測と異なる情報がえられる.今回の計

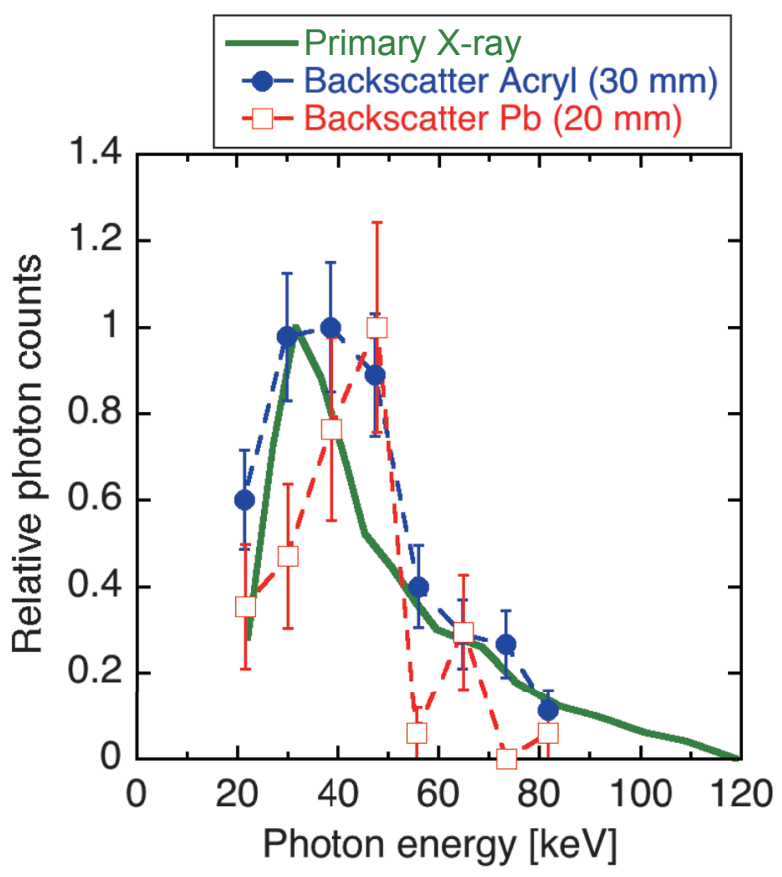

Fig. 6 Backscattered spectrum shifts from the primary Xray. Solid line: Primary X-ray. Circle: Acrylic of $30 \mathrm{~mm}$ thickness. Square: Lead of $20 \mathrm{~mm}$ thickness. 
測でも，銅及び鉛よりもアクリルからの散乱信号強度が 高いことがこの特徴をよく表している.

\section{4. レーザー加速電子のレーザー逆コンプトン散乱 過程によるペンシルビームX線源の開発}

レーザーを金属固体へ照射し制動放射により発生させ るX線は, 発散角がレーザー集光角度以上に広く, 遠方 での強度は距離の二乗で減衰してしまう。一次X線の指 向性を向上するため, 超高強度レーザー加速電子による レーザー光自身の逆コンプトン散乱X線の開発をおこ なっている. 散乱される入射レーザー光のフォトンエネ ルギー $\varepsilon_{L}$ と正面衝突で散乱させる電子ビームのエネル ギー $\gamma m_{e} c^{2}$ に対して, 逆コンプトン散乱光のエネルギー は $E_{\gamma} \sim 4 \gamma^{2} \varepsilon_{L}$, 発散角は $\theta \approx 1 / \gamma$ となるので ${ }^{22}$, 電子ビーム のエネルギー $\gamma$ が大きければ大きいほど, 散乱角は小さ くペンシルビームのように絞り込むことが出来る。これ が応用上, 逆コンプトン散乱光の最大の利点といえる。

レーザー加速電子による逆コンプトン散乱の実証例と して, 我々の結果を紹介する ${ }^{13)}$. 出力4 TWのBEATレー

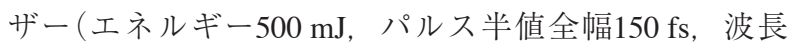
$815 \mathrm{~nm}$ )を, 超音速スリットノズルから吹き出したガス 密度 $9 \times 10^{19} \mathrm{~cm}^{-3}$ のヘリウムガスに照射した. Fig. 8中の ビームスプリッターで $460 \mathrm{~mJ}$ の反射ビーム (1次ビーム) と $30 \mathrm{~mJ}$ の透過ビーム (2次ビーム)に分け, 反射ビームで 航跡場を励起し, 電子ビームを加速する. 反射ビームは 焦点距離 $108 \mathrm{~mm}(\mathrm{f} / 2.2)$, 口径51 mmの軸外し放物面鏡 で, ガスジェットの一方の端にノズルの下方 $2 \mathrm{~mm}$ 位 置で集光する. ジェットノズルスリットは長さ $4 \mathrm{~mm}$, 幅1.2 mmの長方形の開口を持ち, 長手方向をレーザー 軸と平行とする。集光強度は $1.5 \times 10^{18} \mathrm{~W} / \mathrm{cm}^{2}$ である。透 過ビームは焦点距離 $150 \mathrm{~mm}(\mathrm{f} / 3.8)$ ，口径50 mmの凸レン

(a)
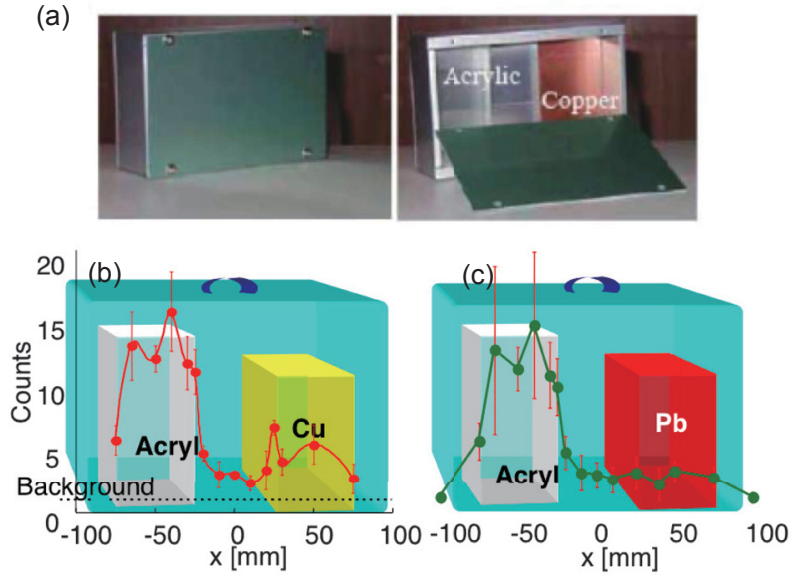

Fig. 7 (a) Sample aluminum container in which the objects are hidden. The container size is $150 \mathrm{~mm} \times$ $100 \mathrm{~mm} \times 50 \mathrm{~mm}$. Inside the container, $30-\mathrm{mm}$ thick acrylic resin (left) and a 5-mm-thick copper or 1-mm-thick lead block (right) are present. (b, c) Backscattered X-ray profiles showing the inside of the container. The backscattered signals are different for (b) acrylic resin $\mathrm{CH}$ (left) and copper $(\mathrm{Cu}$, right) and (c) acrylic (left) and lead ( $\mathrm{Pb}$, right).
ズで他端に集光する。集光強度は $9.2 \times 10^{15} \mathrm{~W} / \mathrm{cm}^{2}$ であ る. 規格化べクトルポテンシャル $a_{0}=e E / m_{e} \omega_{L} c$ は, それ ぞれ0.84と0.064となる。但しEはレーザー電場強度, $\omega_{L}$ はレーザーの角周波数である。2次ビームのスポットサ

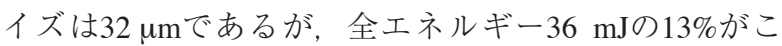
の中に含まれる。上記ビームのパルス圧縮器内での漏れ 光を2倍高調波 $(407 \mathrm{~nm})$ に波長変換し，1次ビームと直 交する方向からへリウムガスに照射し，シェアリング干 渉計でプラズマ密度分布を計測した。

航跡場によって加速された電子ビームのエネルギース ペクトルを計測するために電子分光器(Electron Spectrometer: ESM)を反射ビームの下流に設置した。ダ イポール磁場でエネルギー分解した電子スペクトルをイ メージングプレート (IP) に記録するもので, 検出立体角 は, $3.1 \times 10^{-4} \mathrm{sr}$ で, 最大 $29 \mathrm{MeV}$ まで検出可能である. ガスジェットを発生するパルスバルブへのヘリウムガス 充填圧力が $80 \mathrm{~atm}$ 時のIPの生データと解析したスペク トルをFig. 8 (inbox)に示す.100ショット重ねどりした ものである。解析スペクトルより $14 \mathrm{MeV}$ と $23 \mathrm{MeV}$ に準 単色の電子のピークが見える. $23.3 \mathrm{MeV}$ での電荷量は 100 ショット重ね取りで合計74 fC, 発散角は $2 \mathrm{mrad}$ 算 出される. 充填圧力が $65 \mathrm{~atm}$ ではこのようなピークは見 られず，レーザー強度が足らないためと思われる。

逆コンプトン散乱X線を検出するため, フォトンカウ ンティングモードで動作するX線検出器 (Si-PIN photodiode, XR-100 CR, FWHM: $149 \mathrm{eV}$, Be空厚 $0.5 \mathrm{~mm}$, $\mathrm{Si}$ 厚さ $0.5 \mathrm{~mm}$ )をレーザー光軸上, 2次ビームの上流に設 置した。 Fig. 8にあるようにターゲットから散乱される X線は，先ず集光レンズの中心に開られた直径 $8 \mathrm{~mm}$ の 穴を通り, 長さ $5 \mathrm{~cm}$, 内径 $2 \mathrm{~mm}$ の鉛コリメーターを 通って検出器に到達する。検出器のエネルギー分解能は

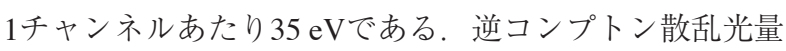
は平均ショットあたり0.1光子と予想され, 1000 ショッ トの重ねどりで結果をえた。散乱光のほとんどは電子 ビームが周辺機器に衝突して発生する直接の制動輻射X

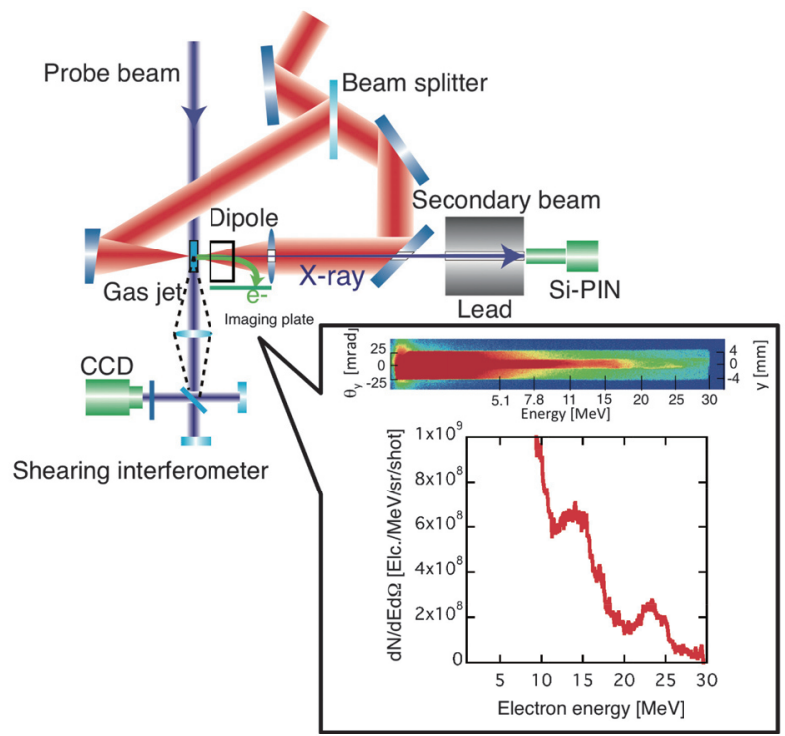

Fig. 8 Setup for the inverse Compton scattering experiment and electron spectra. 
線であり，そのうち逆コンプトン散乱光は $1 \%$ 程度であ る。そのため, 2次ビームの有り無しのデータをまず取 得し(Fig. 9 (inbox)), その差を逆コンプトン散乱光とし Fig. 9にプロットした. 生データは, 11チャンネル毎 $(0.385 \mathrm{keV})$ に平均して赤点でプロットした。 その際の 標準偏差をエラーバーとした。 ショット毎のバラつき は, ターゲットから $1.2 \mathrm{~m}$ の位置のプラスチックシンチ レーターで得られるガンマ線強度をモニターして補正し た。眓中の青線は, Fig. 8 (inbox) から求めた電子ビーム スペクトルをもとに下記の式(1)

$$
\frac{d N_{\gamma}}{d E_{\gamma}}=\frac{\alpha_{f}}{8 \varepsilon_{L}} a_{0}^{2} m_{e} \gamma c^{2} N_{0} \frac{d N_{e}}{d E_{e}} d \Omega
$$

を使って求めたものである。この式で $\alpha_{f}$ は微細構造定 数, $N_{0}$ は2 次ビームのレーザーの振動子数, $N_{e}$ は衝突電 子数を意味する. 加速電子のエネルギースペクトルは,

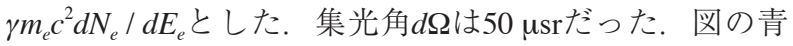

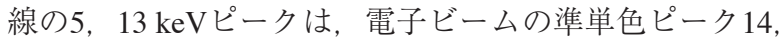
$23 \mathrm{MeV}$ に対応する逆コンプトン散乱光の計算值であ る. 赤線の検出されたX線ピークの6と $11 \mathrm{keVがこれら}$ に対応する実際の逆コンプトン光と考えられる. 27 と $34 \mathrm{keV}$ のピークも逆コンプトン光のようであるが, これ に対応する電子のエネルギーは34と38 MeVであり ESM の計測限界を超えていたため, これらのエネルギーに ピークが存在したかは不明である。 $2 \mathrm{keV}$ 以下のX線は, 検出器の前面の空で遮断されるので， $3 \mathrm{keV}$ 見える ピークは逆コンプトン散乱に起因するものではない.

Fig. 9のY軸左側に実験で得られたフォトン数(赤線), Y 軸右側に計算で得られるフォトン数(青線)をプロットし ている，実験值と計算值を比較すると，計算予測值が実 験結果の5倍ほど高い值を示しているが，これは実験に おいて2次ビームのプラズマ中での減衰及び衝突夕イミ ングを含めたアライメント精度が影響し，電子ビームと 衝突する2次ビームの強度が低下していたためと推定さ れる，定性的なスペクトル分布がほぼ一致している事か
ら，実験的に得られた散乱光は逆コンプトン散乱光であ る可能性が高いと結論される.

\section{5. 実証機にむけた検討}

レーザー生成X線による後方散乱遠隔透視技術を, Fig. 3に示したような実証機にまで成熟させるために， 主な技術課題及び仕様を整理し，Table 1に示した。第一 課題は, 現在進めている超高強度レーザー加速電子によ るレーザー光自身の逆コンプトン散乱X線のペンシル ビーム化である。ペンシルビームX線源が開発されれ ば，検出原理として採用している後方散乱の物理は単純 であるため，後は技術成熟度が決め手となり，課題とし て装置の可搬性, 一次X線源のスキャニング精度及び再 現性が挙げられる。散乱X線検出器に時間分解機能が追 加されれば, 断層の計測が可能となるため, 非破壊検査 等への適用が期待される。具体的な数值目標として, X 線エネルギー $160 \mathrm{keV}$ 以上, 拡がり角 $6 \mathrm{mrad}$ 以下を実現 L1 m遠方の模擬物体の遠隔断層情報取得を揭げてい る.

\section{6. まとめ}

レーザー生成X線で, 後方散乱による遠隔透視が原理 的に可能であることを示した。自然放射線レベル以下の 微弱な散乱光を入射X線との同期計測で，その材質，形 状の推測ができることを示した。レーザー生成X線の指 向性向上のため, 超高強度レーザー加速電子によるレー ザー光自身の逆コンプトン散乱X線発生を試み，エネル ギー2 $23 \mathrm{MeV}$ 準単色電子による $10 \mathrm{keV}$ の線発生を確認し た。今後は，X線エネルギー $160 \mathrm{keV}$ 以上，拡がり角 $6 \mathrm{mrad}$ 以下を実現し $1 \mathrm{~m}$ 遠方の模擬物体の遠隔断層情報 取得を目指す。

Table 1 Technical issues and their specifications to realize a stand-off detection system by laser plasma induced X-ray.

\begin{tabular}{cl}
\hline \multicolumn{1}{c}{ Technical issue } & \multicolumn{1}{c}{ Specifications } \\
\hline \hline $\begin{array}{c}\text { 1. High-intense pencil } \\
\text { beam X-ray }\end{array}$ & $\begin{array}{l}\text { Energy }>160 \mathrm{keV} \\
\text { Divergence }<6 \mathrm{mrad} \\
\text { Repetition }>0.5 \mathrm{~Hz}\end{array}$ \\
$\begin{array}{c}\text { 2 Stand-off detection } \\
\text { of a dummy object }\end{array}$ & $\begin{array}{l}\text { Time resolution }<200 \mathrm{ps} \\
\text { Space resolution }<3 \mathrm{~cm}\end{array}$ \\
& Shield thickness $>1 \mathrm{~cm}$ \\
3. Scanning of the pencil & Horizontal scan range $> \pm 20^{\circ}$ \\
beam X-ray & Vertical scan range $>0-20^{\circ}$ \\
& Resolution $<0.2^{\circ}$ \\
4. Acquisition of & Stand-off distance: $1 \mathrm{~m}$ \\
2-dimensional & Shield: earth and sand $1 \mathrm{~cm}$ \\
perspective image & Dummy: plastics $20 \mathrm{~cm}$ \\
\hline
\end{tabular}




\section{謝 辞}

本レーザー装置は, 平成13～17年度放射線医学総合研 究所文部科学省委託 $\lceil$ 先進小型加速器の要素技術の普及 技術」及び光産業創成大学院大学産業創成研究費によっ て整備され, 本研究の一部は, 光産業創成大学院大学学 内プロジェクト, IHI - 光産業創成大学院大学共同研究, 平成20２2年度日本私立学校振興 · 共済事業団学術研究 振興資金, 日本学術振興会科学研究費補助金基盤A (21244088) 及び大阪大学レーザーエネルギー学研究セン ター共同研究による。

\section{参考文献}

1）莱原一, 森芳孝：放射線と産業 116 (2007) 44

2) H. Kuwabara, Y. Mori, and Y. Kitagawa: J. Plasma Fusion Res. 3 (2008) 003.

3) 葉原一: 博士学位論文, 光産業創成大学院大学, 浜松 2008 .
4) L. M. Chen, M. Kando, J. Ma, H. Kotaki, Y. Fukuda, Y. Hayashi, I. Daito, T. Homma, K. Ogura, M. Mori, et al.: Appl. Phys. Lett. 90 (2007) 211501

5) C. M. Laperle, P. Wintermeyer, J. R. Wands, D. Shi, M. A Anastasio, X. Li, B. Ahr, G. J. Diebold, and C. Rose-Petrucka: Appl. Phys. Lett. 91 (2007) 173901.

6) Y. Oishi, T. Nayuki, C. Nakajima, T. Fujii, A. Zhidkov, and K. Nemoto: Jpn. J. Appl. Phys. 49 (2010) 046602.

7) S. Cipiccia, M. R. Islam, B. Ersfeld, R. P. Shanks, E. Brunetti, G. Vieux, X. Yang, R. C. Issac, S. M. Wiggins, G. H. Welsh, et al.: Nature Phys. 7 (2011) 867.

8) K.Tanaka, S. Ishii, R. Kuroda, H. Toyokawa, E. Miura: Proc. 8th Annual Meeting of Particle Accelerator Society of Japan (Tsukuba, Japan, 2011) MOPS120.

9) K. Ta Phuoc, S. Corde, C. Thaury, V. Malka, A. Tafzi, J. P Goddet, R. C. Shah, S. Sebban, and A. Rousse: Nature Photon. 6 (2012) 308.

10) Y. Mori, S. Fukumochi, Y. Hama, K. Kondo, Y. Sentoku, and Y. Kitagawa: Int. J. Mod. Phys. B 21 (2007) 572.

11) Y. Mori and Y. Kitagawa: Phys. Plasmas 19 (2012) 053106.

12) H. Schwoerer, B. Liesfeld, H.-P. Schlenvoigt, K.-U. Amthor, and R. Sauerbrey: Phys. Rev. Lett. 96 (2006) 014802.

13) Y. Mori, H. Kuwabara, K. Ishii, R. Hanayama, T. Kawashima, and Y. Kitagawa: Appl. Phys. Express 5 (2012) 056401. 